\title{
Bousbach
}

AFUL des Cerisiers

\section{Xavier Antoine}

\section{(2) OpenEdition}

1 Journals

Édition électronique

URL : http://journals.openedition.org/adlfi/8925

ISSN : 2114-0502

Éditeur

Ministère de la culture

Référence électronique

Xavier Antoine, "Bousbach», ADLFI. Archéologie de la France - Informations [En ligne], Lorraine, mis en ligne le 01 mars 2001, consulté le 20 avril 2019. URL : http://journals.openedition.org/adlfi/8925

Ce document a été généré automatiquement le 20 avril 2019.

(c) Ministère de la Culture et de la Communication, CNRS 


\title{
Bousbach
}

\author{
AFUL des Cerisiers
}

\section{Xavier Antoine}

Identifiant de l'opération archéologique : F1357200100019

Date de l'opération : 2001 (EV)

1 À l'occasion d'un projet de lotissement à usage d'habitation (39 lots) portant sur une surface de $29493 \mathrm{~m}^{2}$, le service régional de l'Archéologie de Lorraine a procédé à un diagnostic, qui n'a pas révélé la présence de vestiges archéologiques.

INDEX

Index géographique : Lorraine, Moselle (57), Bousbach operation Fouille d'évaluation (EV)

\section{AUTEURS}

XAVIER ANTOINE

AFAN 